\title{
Optical coherence tomography for guidance of treatment of in-stent restenosis with cutting balloons
}

\author{
Gioel Gabrio Secco ${ }^{1-3}$, MD; Nicolas Foin², Msc; Nicola Viceconte', MD; Francesco Borgia ${ }^{1}$, MD; \\ Giuseppe De Luca³, MD, PhD; Carlo Di Mario ${ }^{1 *}, \mathrm{MD}$, PhD, FESC, FACC, FRCP, FSCAI \\ 1. Cardiovascular Biomedical Research Unit, Royal Brompton \& Harefield NHS Foundation Trust, London, United Kingdom; \\ 2. Department of Bioengineering, Imperial College, London, United Kingdom; 3. University of Eastern Piedmont, "Maggiore \\ della Carità" Hospital, Novara, Italy
}

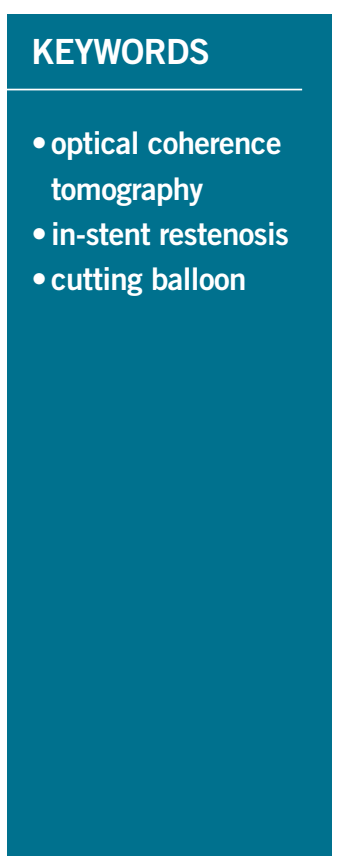

\begin{abstract}
Aims: The treatment of in-stent restenosis (ISR) remains a challenge with poor immediate results and higher restenosis rate than in de novo lesions. We propose, based on a consecutive series of patients treated with cutting balloon, a strategy of aggressive device selection based on the results of serial FD-OCT assessment.

Methods and results: Fourteen consecutive ISR lesions were evaluated both angiographically and with frequency domain optical coherence tomography (FD-OCT) (C7; LightLab Imaging Inc., Westford, MA, USA). Cutting balloon (CB) was used in all cases, sized firstly according to conventional angiographic criteria and then upgraded based on OCT assessment with the aim of creating cuts as close as possible to the struts. OCT data analysis included measurements of lumen and stent area, minimal distance lumen-struts and residual plaque neointimal hyperplasia. With an OCT guided CB strategy, the final minimal lumen cross-sectional area (MLCSA) after the final treatment reached $6.68 \pm 1.14 \mathrm{~mm}^{2}$, with a reduction from $69 \%$ to $25 \%$ of neointimal hyperplasia. In the patients with a two-step strategy using a first CB guided by angiography and a second CB guided by OCT, the increase in CB diameter was $0.5 \mathrm{~mm}$, achieving an increase in MLCSA area from $4.9 \pm 0.42$ to $6.35 \pm 0.92 \mathrm{~mm}^{2}$ with a reduction from $41 \%$ to $27 \%$ of neointimal hyperplasia.
\end{abstract}

Conclusions: The OCT measurements of strut-to-strut distance allow safe upsizing of the $\mathrm{CB}$ with an acceptable lumen increase before deployment of a new DES. The strategy appears of particular usefulness for a DEB strategy with no intention to implant new stents.

\footnotetext{
*Corresponding author: Royal Brompton Hospital, Sydney Street, London SW3 6NP, United Kingdom. E-mail: c.dimario@rbht.nhs.uk
} 


\section{Introduction}

In stent restenosis (ISR) has become less frequent after the introduction of drug-eluting stents (DES), but when restenosis develops long-term outcome appears much less satisfactory than after initial DES implantation ${ }^{1-3}$.

Intravascular ultrasound (IVUS) can be used in the assessment of ISR because of its ability to distinguish inadequate expansion from neointimal proliferation and guide further treatment (ACC/AHA PCI Guidelines, Class II, Level of Evidence: B) ${ }^{4}$.

IVUS studies ${ }^{5-7}$ have shown that, despite the use of larger balloons, higher pressure and new stents, the final minimal lumen cross-sectional area (MLCSA) achieved was smaller than the minimal stent cross-section area (MSCSA) after initial stent deployment. We hypothesised that this was due to the inability to apply direct pressure to the previously deployed stent due to the cushion-like protection of the neointima, precluding adequate stent expansion. We tested an alternative treatment strategy based on the use of cutting balloons (CB) sized with optical coherence tomography (OCT) to achieve effective cutting as close as possible to the struts, allowing subsequent better extrusion of the neointima outside the stent and direct transmission of the expanding force of the balloon to the stent struts.

OCT has greater resolution than IVUS allowing for detecting thin-capped fibroatheroma (TCFA) and apposition of stent struts ${ }^{8-11}$, but its use for guidance of intervention is limited by the need of prolonged crystalloid infusion during imaging. Frequency domain OCT (FD-OCT), due to its fast-scanning laser systems, allows multiple acquisitions of the entire segment of interest with an amount of contrast only slightly greater than contrast required for the control angiogram $^{12}$. The lack of penetration of OCT, a problem for the detection of the external elastic membrane (EEM)-area in the diseased segments, is of limited importance for ISR because the struts of the previously deployed stent have so high a backscatter as to allow easy identification through the neointimal layer ${ }^{13}$.

We used FD-OCT to precisely follow the irregular lumen contour after $\mathrm{CB}$ to guide $\mathrm{CB}$ sizing and results in 11 consecutive ISR lesions.

\section{Methods}

We assessed 14 consecutive ISR lesions involving the right coronary artery $(n=2)$, left circumflex $(n=6)$, left anterior descending $(n=4)$, first diagonal branch $(n=1)$ and a saphenous vein graft to RCA ( $n=1)$. All the stents initially implanted in the restenotic segment were DES (Table 1).

Angiographic and optical coherence tomography images acquisition (Table 2).

ISR lesions were classified according to Mehran et $\mathrm{al}^{14}$ as the following:

- Class I: (focal ISR): lesion $<10 \mathrm{~mm}$ in length and positioned at the unscaffolded segment, the body of the stent, the proximal or distal margin (not both) or a combination of these sites.

- Class II: (diffuse intrastent ISR): lesion $>10 \mathrm{~mm}$ in length and confined to the stent, without extending outside the margins.

- Class III: (diffuse proliferative ISR): lesion $<10 \mathrm{~mm}$ in length extending beyond the margins.

- Class IV: ISR with total occlusion.
Table 1. Months after stent implantation, type of stent used and angiographic findings.

\begin{tabular}{|l|c|c|c|c|c|c|c|}
\hline Vessel & Months & $\begin{array}{c}\text { Type of } \\
\text { stent }\end{array}$ & $\begin{array}{c}\text { Length } \\
(\mathbf{m m})\end{array}$ & $\begin{array}{c}\text { Diam } \\
(\mathbf{m m})\end{array}$ & $\begin{array}{c}\text { P } \\
\text { ATM }\end{array}$ & $\begin{array}{c}\text { Visual } \\
\text { angiographic } \\
\text { stenosis }\end{array}$ & $\begin{array}{c}\text { Mehran } \\
\text { classifica- } \\
\text { tion }\end{array}$ \\
\hline LCX & 15 & ZES & 24 & 3.0 & 33 & $90 \%$ & I \\
\hline LCX & 49 & PES & 18 & 3.0 & 18 & $50 \%$ & I \\
\hline RCA & 3 & EES & 23 & 3.0 & 26 & $60 \%$ & I \\
\hline DG1 & 59 & PES & 24 & 2.5 & 24 & $75 \%$ & II \\
\hline LADd & 5 & EES & 24 & 2.5 & 24 & $90 \%$ & I \\
\hline LCX & 8 & SES & 23 & 2.75 & 30 & $95 \%$ & III \\
\hline LCXd & 8 & SES & 23 & 2.25 & 24 & $75 \%$ & II \\
\hline LCX & 17 & EES & 8 & 3.0 & 12 & $80 \%$ & III \\
\hline LADd & 10 & SES & 18 & 3.0 & 20 & $100 \%$ & IV \\
\hline RCA & 14 & SES & 23 & 3.5 & 24 & $100 \%$ & IV \\
\hline LCX & 9 & PES & 18 & 3.5 & 20 & $100 \%$ & IV \\
\hline LAD & 7 & PES & 24 & 3.0 & 16 & $60 \%$ & I \\
\hline LAD & 60 & SES & 23 & 3 & 14 & $70 \%$ & I \\
\hline SVG to RCA & 5 & EES & 24 & 2.75 & 16 & $60 \%$ & II \\
\hline ZES: & & & & & & \\
\hline
\end{tabular}

ZES: zotarolimus-eluting stent (Endeavor, Medtronic, Minneapolis, MN, USA); PES. paclitaxel-eluting stent (Taxus Express, Boston Scientific, Natick, MS, USA); EES: everolimus-eluting stent (Promus, Boston Scientific, Natick, MS, USA; Xience, Abbott, Abbott Park, Illinois, USA); SES: sirolimus-eluting stent (Cypher, Cordis, Johnson \& Johnson, Warren, NJ, USA

Subsequently, OCT acquisition was performed with a frequency domain analysis system (C7; LightLab Imaging Inc., Westford, Massachusetts, USA). A motorised pullback at $2 \mathrm{~cm} / \mathrm{s}$ was activated during injection of iodixanol 320 (Visipaque, GE Health Care, Cork, Ireland) via 6 or 7 Fr guiding catheter at a flow rate sufficient to have full substitution of blood with contrast with no streaming (non-occlusive technique $)^{15}$. The position of the imaging probe at the time of the start of pull-back was documented angiographically. Frames were analysed every $0.5 \mathrm{~mm}$. Anatomical landmarks such as side branches, calcifications, or stent edges were used for longitudinal orientation.

\section{OPTICAL COHERENCE TOMOGRAPHY DATA ANALYSIS}

Qualitative and quantitative analysis of OCT images was performed offline using proprietary software (C7, LightLab Imaging). MLCSA and MSCSA were measured before and after each CB inflation and after stent deployment and high pressure post-expansion. Neointimal area was calculated by subtracting the luminal area from the stent area. The minimal distance between neointimal fissures created by the microatherotome blades and stent struts was calculated after each cutting balloon inflation. The first $\mathrm{CB}$ was selected by the operator according to the visual estimation of the angiographic reference diameter. In three patients, a smaller conventional balloon had to be used for initial predilatation because of the impossibility 
Table 2. OCT data analysis.

\begin{tabular}{|c|c|c|c|c|c|c|c|c|c|c|c|c|c|c|c|c|c|c|c|}
\hline VESSEL & $\begin{array}{c}\text { MLCSA } \\
\mathrm{mm}^{2}\end{array}$ & $\begin{array}{c}\text { MSCSA } \\
\mathrm{mm}^{2}\end{array}$ & $\begin{array}{l}\text { NEOIN- } \\
\text { TIMAL } \\
\text { AREA } \\
\text { mm }^{2}\end{array}$ & $\begin{array}{l}\text { CB1 } \\
\mathrm{mm}\end{array}$ & $\begin{array}{c}P \\
\text { ATM }\end{array}$ & $\begin{array}{c}\text { MLCSA } \\
\mathrm{mm}^{2}\end{array}$ & $\begin{array}{c}\text { MSCSA } \\
\mathrm{mm}^{2}\end{array}$ & $\begin{array}{c}\text { NEOIN- } \\
\text { TIMAL } \\
\text { AREA } \\
\mathrm{mm}^{2}\end{array}$ & $\begin{array}{l}\text { CB2 } \\
\mathrm{mm}\end{array}$ & $\begin{array}{c}P \\
\text { ATM }\end{array}$ & $\begin{array}{c}\text { MLCSA } \\
\mathrm{mm}^{2}\end{array}$ & $\begin{array}{c}\text { MSCSA } \\
\mathrm{mm}^{2}\end{array}$ & $\begin{array}{c}\text { NEOIN- } \\
\text { TIMAL } \\
\text { AREA } \\
\mathrm{mm}^{2}\end{array}$ & $\begin{array}{l}\text { STENT } \\
\text { USED }\end{array}$ & $\begin{array}{c}\text { DIAM } \\
\mathrm{mm}\end{array}$ & $\begin{array}{c}\mathbf{P} \\
\text { ATM }\end{array}$ & $\begin{array}{c}\text { MLCSA } \\
\mathrm{mm}^{2}\end{array}$ & $\begin{array}{c}\text { MSCSA } \\
\mathrm{mm}^{2}\end{array}$ & $\begin{array}{c}\text { NEOIN- } \\
\text { TIMAL } \\
\text { AREA } \\
\text { mm }^{2}\end{array}$ \\
\hline LCX & 1.15 & 6.82 & 5.67 & 3.0 & 16 & 4.4 & 8.46 & 4.06 & 3.5 & 16 & 5.4 & 8.66 & 3.26 & & & & 5.4 & 8.66 & 3.26 \\
\hline LCX & 2.78 & 7.63 & 4.85 & 3.0 & 16 & 6.17 & 9.4 & 3.23 & & & & & & & & & 6.17 & 9.4 & 3.23 \\
\hline RCA & 2.77 & 7.25 & 4.48 & 3.0 & 16 & & & & & & & & & ZES & 2.75 & 18 & 5.98 & 9.49 & 3.51 \\
\hline DG1 & 1.61 & 5.47 & 3.86 & 2.5 & 18 & 3.49 & 5.85 & 2.36 & & & & & & EES & 2.75 & 18 & 4.67 & 6.02 & 1.35 \\
\hline LAD & 3.27 & 6.29 & 3.02 & 3.0 & 14 & 6.18 & 7.36 & 1.18 & & & & & & EES & 3.0 & 16 & 6.49 & 7.48 & 0.99 \\
\hline LCX & 3.6 & 8.48 & 4.88 & 2.5 & 18 & & & & 3.0 & 16 & 4.98 & 8.54 & 3.56 & EES & 3.0 & 24 & 7.46 & 8.66 & 1.2 \\
\hline LCX & 2.85 & 5.61 & 2.76 & 2.5 & 18 & 4.73 & 6.24 & 1.51 & 3.0 & 12 & 5.72 & 6.78 & 1.06 & EES & 2.75 & 18 & 6.09 & 7.01 & 0.92 \\
\hline LCX & 1.75 & 6.48 & 4.73 & 3.0 & 10 & 3.88 & 7.99 & 4.11 & & & & & & EES & 3.0 & 10 & 5.84 & 8.23 & 2.39 \\
\hline LAD & $1.54^{*}$ & 7.13 & 5.59 & 2.5 & 16 & 5.39 & 8.03 & 2.64 & 3.0 & 16 & 7.21 & 8.65 & 1.44 & PES & 3.0 & 14 & 8.09 & 9.39 & 1.3 \\
\hline RCA & $1.65^{*}$ & 10.23 & 8.58 & 3.0 & 16 & 5.08 & 10.39 & 5.31 & 3.5 & 16 & 7.09 & 10.98 & 3.89 & EES & 3.5 & 24 & 8.87 & 11.2 & 2.33 \\
\hline LCX & $1.87^{*}$ & 8.32 & 6.45 & 3.5 & 16 & 6.72 & 8.98 & 2.26 & & & & & & EES & 3.5 & 24 & 7.26 & 9.42 & 2.16 \\
\hline LAD & 2.04 & 5.87 & 3.83 & 3.0 & 12 & 5.19 & 8.03 & 2.84 & & & & & & EES & 3.0 & 12 & 6.83 & 8.55 & 1.72 \\
\hline LAD & 2.53 & 6.27 & 3.74 & 3.5 & 12 & 6.96 & 9.1 & 2.14 & & & & & & EES & 3.5 & 12 & 7.95 & 9.66 & 1.71 \\
\hline SVG to RCA & 1.77 & 6.35 & 4.58 & 3.0 & 18 & 4.13 & 7.46 & 3.33 & & & & & & ZES & 3.5 & 18 & 6.52 & 7.76 & 1.24 \\
\hline mean & 2.22 & 7.01 & 4.78 & & & 5.19 & 8.10 & 2.91 & & & 6.08 & 8.72 & 2.64 & & & & 6.68 & 8.63 & 1.95 \\
\hline$S D \pm$ & 0.73 & 1.30 & 1.48 & & & 1.12 & 1.29 & 1.17 & & & 1.01 & 1.49 & 1.29 & & & & 1.14 & 1.29 & 0.88 \\
\hline
\end{tabular}

to perform OCT in a total occluded vessel. In two patients, a smaller conventional balloon had to be used for initial predilatation because the $\mathrm{CB}$ did not cross directly. In a tortuous RCA the CB could be used only in a proximal, but not in the distal segment of the ISR. The CB diameter was then upsized based on the OCT assessment of the stent diameter aiming at achieving a $\mathrm{CB} /$ stent ratio of 1.11.2/1.0. New DES were implanted in all patients, except two lesions with small diameters and multiple previously implanted stents in which the operator felt that a sufficient result was achieved with $\mathrm{CB}$ dilatation only (Figures 1 and 2). No dissections requiring new stent implantation were observed after the final OCT acquisition.

\section{Results}

\section{ANGIOGRAPHIC ANALYSIS (TABLE 1)}

Of the ISR lesions treated six were focal, three had diffuse ISR, two had diffuse proliferative ISR and three had a total occlusive restenosis.

\section{OPTICAL COHERENCE TOMOGRAPHY ANALYSIS (TABLE 2)}

The mean MCSA of the lumen and stent pre-treatment was respectively $2.22 \pm 0.73 \mathrm{~mm}^{2}$ and $7.01 \pm 1.30 \mathrm{~mm}^{2}$. The mean MCSA lumen after first and second cutting balloon inflation, were respectively $5.19 \pm 1.12 \mathrm{~mm}^{2}$ and $6.08 \pm 1.01 \mathrm{~mm}^{2}$. The mean final MCSA lumen was $6.68 \pm 1.14 \mathrm{~mm}^{2}$. In the patients with a two-step strategy using a first $\mathrm{CB}$ guided by angiography and a second CB guided by OCT, the increase in $\mathrm{CB}$ diameter was $0.5 \mathrm{~mm}$, achieving an increase in MLCSA area from $4.9 \pm 0.42$ to $6.35 \pm 0.92 \mathrm{~mm}^{2}$ with a reduction from $41 \%$ to $27 \%$ of neointimal hyperplasia (Figures 3 and 4 ).

\section{CLINICAL FOLLOW-UP}

In-hospital, 30 days, and cumulative 6-month MACE were defined as death, myocardial infarction and repeat revascularisation (CABG or PTCA). Twelve-lead electrocardiograms were recorded before, immediately after the procedure and at hospital discharge.

\section{Discussion}

Cutting balloons are used for treatment of ISR mainly because of their practical advantage of not moving during inflation due to the stabilising effect of the blades, preventing damage outside the stenting segment (watermelon seeding effect).

The lack of clinical benefit observed in the early studies of CB vs. conventional PTCA in de novo lesions or after treatment of ISR have created scepticism on the potential mechanical advantage offered by a focal concentration of force on the intimal plaque. Hoop stress is a circumferential stress in the vessel wall that balances the intra-arterial 


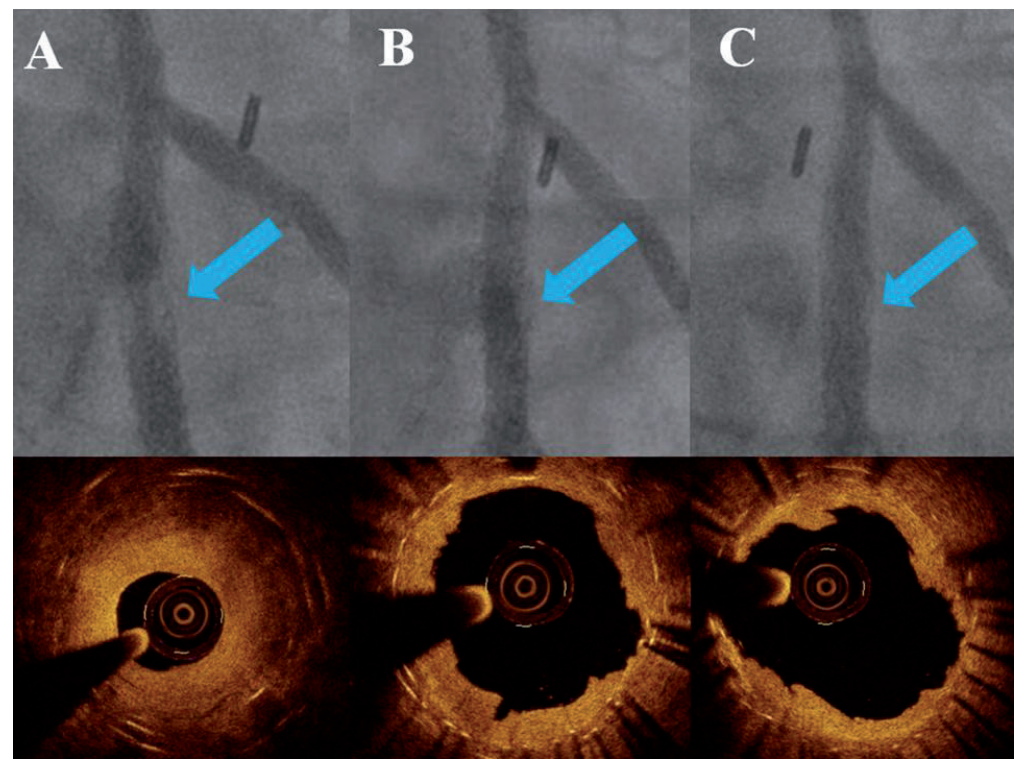

Figure 1. Lesion treated with only cutting balloon expansion. A: Angiogram and OCT pre-treatment: a thick, nearly concentric layer of hyperplasia is revealed by the OCT examination inside a double crown of struts due to the deployment of a 3.0 EES stent inside a 3.5 bare metal stent. B: Angiogram and OCT after $3.0 \times 10 \mathrm{~mm} \mathrm{CB} \mathrm{(16} \mathrm{ATM):} \mathrm{the} \mathrm{lumen} \mathrm{is} \mathrm{improved,} \mathrm{but} \mathrm{there} \mathrm{is} \mathrm{a} \mathrm{filling} \mathrm{defect} \mathrm{inside} \mathrm{the} \mathrm{stent} \mathrm{due} \mathrm{to} \mathrm{residual}$ hyperplasia; the corresponding OCT image indicates that a deep cut approaching the struts is present only in one direction (4 o'clock); based on the stent diameter a larger CB is selected. C: Angiogram and OCT after $3.5 \times 10 \mathrm{~mm} \mathrm{CB} \mathrm{(16} \mathrm{ATM):} \mathrm{the} \mathrm{good} \mathrm{angiographic} \mathrm{result} \mathrm{is} \mathrm{explained}$ by the second deep cut (struts in contact with the lumen at $4 o^{\prime}$ 'clock and $9 o^{\prime}$ 'clock) with MLCSA increased from $4.4 \mathrm{~mm}^{2}$ to $5.4 \mathrm{~mm}^{2}$.

pressure and prevents vessel expansion ${ }^{16}$. In a pressurised vessel where " $r$ " is the inner radius and " $\mathrm{R}$ " is the outer radius, the hoop stress can be estimated by the Laplace law: $\sigma=\mathrm{P}(\mathrm{R}+\mathrm{r}) /(\mathrm{R}-\mathrm{r})$, where "P" is the pressure on the vessel wall ${ }^{17}$. During PTCA, balloons are often inflated with pressures of up to 20 ATM (2025 kPA), 150 times higher than the normal arterial wall pressure (approxi- mately $100 \mathrm{mmHg}=13 \mathrm{kPa}=0.13 \mathrm{ATM})$. The mechanical properties of the arterial wall are critically dependent on the thickness of the wall and the characteristics of the intimal plaque ${ }^{18}$. Consequently, the balloon pressure necessary to achieve circumferential overstretch and a satisfactory lumen expansion is intrinsically dependent of the tissue property and wall thickness. Thick neointimal hyperplasia and the

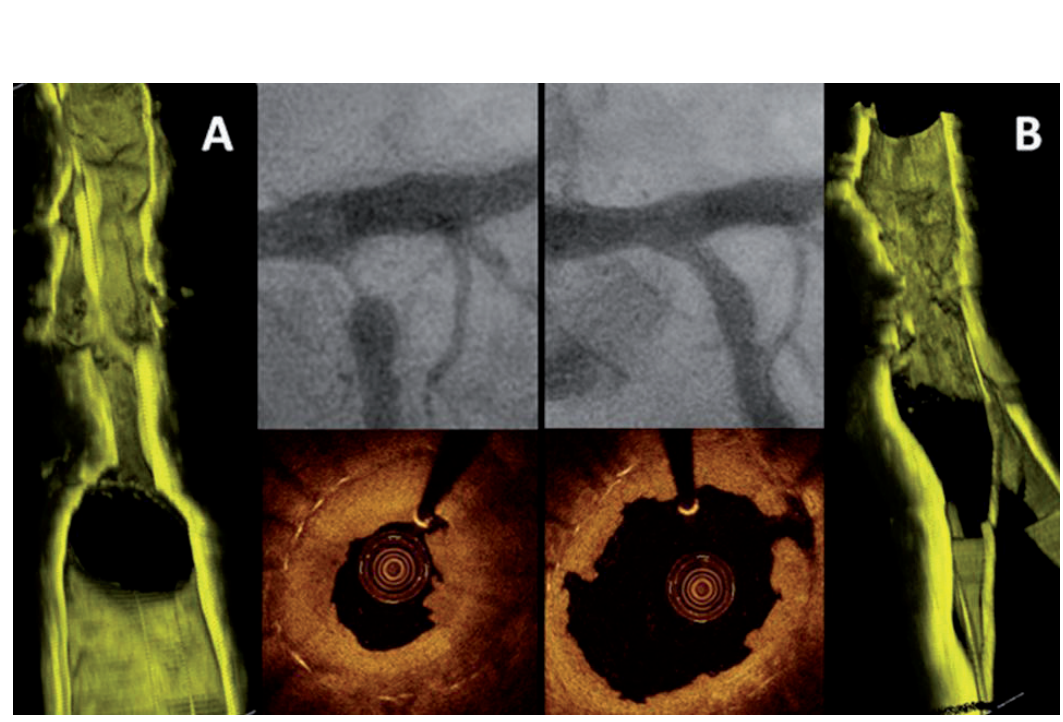

Figure 2. OCT 3-D reconstruction of a plaque treated by cutting balloon expansion. A: Angiogram, OCT and OCT 3-D reconstruction pre-treatment: a thick layer of intimal thickening justifies the severe stenosis. Please note that the OCT image has been obtained after predilation with a $2.0 \mathrm{~mm}$ balloon while the angiogram is before treatment. B: Angiogram, OCT and OCT 3-D reconstruction after CB $3.0 \times 10 \mathrm{~mm}$ (16 ATM): An acceptable and regular lumen has been created by the dilatation with some struts visible in the corresponding $3 D$ reconstruction 


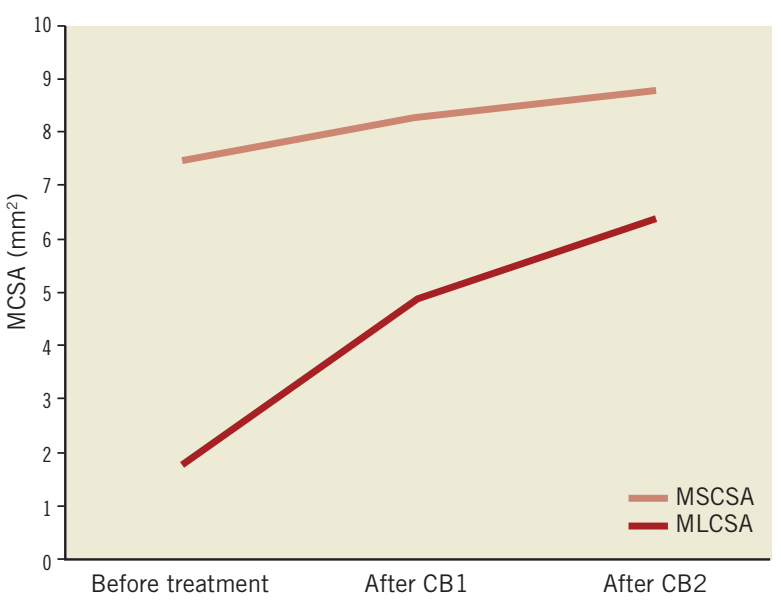

Figure 3. Increase in MLCSA and MCSA of the stent in four patients treated with a two-step strategy: first $C B$ guided by angiography and second $C B$ guided by OCT (Please note that the increase in $C B$ diameter was $0.5 \mathrm{~mm}$, achieving an increase in MLCSA from $4.9 \pm 0.42$ to $6.35 \pm 0.92 \mathrm{~mm}^{2}$ ).

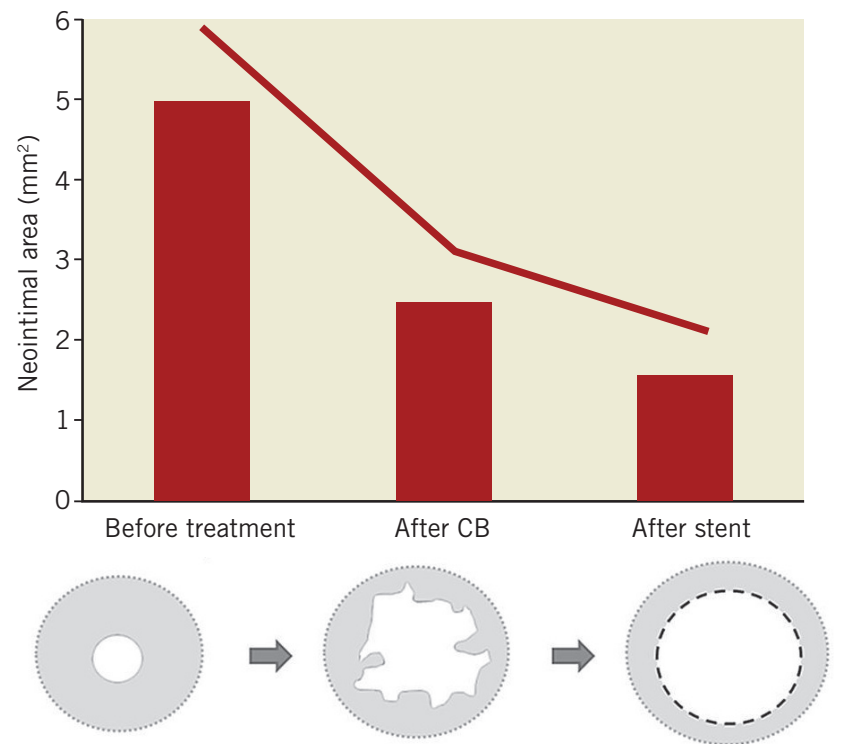

Figure 4. Mean reduction in neointimal plaque area in 11 patients with FD-OCT examinations available both after CB expansion and stent deployment. (Two patients were excluded because they were treated only with $C B$ and one patient was excluded because no OCT examination was performed after $C B$ expansion). The neointimal area after stent implantation was considered the tissue located between the two stents layers.

stent itself contribute to increase the hoop stress to the point that even high-pressure non-compliant balloons might be insufficient to overcome the hoop stress and induct a persistent plastic deformation of the vessel wall ${ }^{19}$.

CBs have been designed to relieve the vessel hoop stress by creating controlled small incisions in the vessel wall. CBs present several advantages for the treatment of ISR, allowing a larger luminal gain at lower pressure compared to PCTA alone and preventing the late elastic recoil due to the incisions created by the blades ${ }^{20}$.

When CBs were compared with conventional balloons for treatment of ISR, the advantages observed in registries ${ }^{21}$ were not confirmed in appropriately sized randomised trials ${ }^{22}$. These trials were performed in the BMS era and without systematic IVUS guidance, not allowing the distinction between ISR due to stent underexpansion, unlikely to respond better to $\mathrm{CB}$, and ISR due to excessive neointimal proliferation, as in all cases in this case series where IVUS was already used in most cases before and after stenting. IVUS is seldom used to check the adequacy of the effect of CB because of its inability to detect the cuts in most of the cases. Suzuki et al, studying animal and in vitro models of ISR, demonstrated that IVUS tends to overestimate lumen area and underestimate the signal-poor in-stent hyperplasia ${ }^{9}$. The OCT measurements were closer to the histological measurements because of the better delineation of the neointima-lumen interface ${ }^{10}$. Balloon angioplasty was the initial strategy for treatment of ISR and proved to be user friendly and associated with good initial results, low incidence of in-hospital complications but relatively high late-repeat ISR. In an IVUS study investigating treatment of ISR, Mehran et $\mathrm{al}^{23}$ demonstrated that when treating ISR with PCTA, luminal gain is achieved by a combination of additional stent expansion and neointimal tissue compression through the stent resulting in a displacement through the stent strut and compression of neointimal tissue. Although satisfactory initial clinical and angiographic results were obtained with balloon angioplasty, a significant early lumen loss was also observed shortly after ISR treatment due to recoil and re-intrusion of neointimal tissue in the lumen ${ }^{24}$. This early phenomenon possibly influences the longterm outcome after POBA for ISR, affected by a high re-restenosis rate $^{25,26}$. CBs, compared with conventional angioplasty balloons, present the significant advantage that the incisions of the microblades reduce the recoil of neointimal tissue into the lumen, allowing greater stent expansion by reducing the hoop stress in the neointimal tissue. This explanation is based on a previous study that demonstrated a greater capacity of $\mathrm{CB}$ over PCTA to extrude fibrous plaque and residual neointimal tissue out of the stent struts. OCT has been shown to be a highly valuable tool to identify pattern and severity of restenosis ${ }^{8}$ as well as to study its mechanisms. Furthermore, due to its high resolution, OCT is able to provide detailed characteristics of restenotic lesions, such as the presence of neovascular formation in the neointimal tissue, and identify the changes induced by the thin cuts of the $\mathrm{CB}$ blades. In fact, using OCT, we were able to guide the selection of the $\mathrm{CB}$ based on the distance between neointimal fissures created by the microblades and stent struts in order to eventually upgrade the $\mathrm{CB}$ diameter when the result was unsatisfactory. We believe that this allows greater expansion of the DES implanted in most cases as the final step of treatment, and has the potential of an even greater advantage if drug eluting balloons are used. This can lead to a greater MLCSA in order to achieve the largest final lumen, providing a "safety margin" for possible reactive hyperplasia ("bigger-is-better"). In fact, in all of the 14 ISR lesions we were able to achieve a satisfactory final MLCSA, always greater than $5.0 \mathrm{~mm}^{2}$, considered to be a valuable predictor for the long-term stent patency ${ }^{27}$. 


\section{Limitations}

The major limitation of this pilot study is the small size of the study population, justified by the rarity of restenoses after DES and, especially, DES restenoses with significant intimal hyperplasia. However, while DES are implanted in more than $90 \%$ of our practice, and second generation DES are likely to reduce even more the phenomenon, other countries still use a majority of BMS or do not have second generation DES available.

Another limitation of our study is the lack of angiographic follow-up, however, initial clinical follow-up data are encouraging.

The OCT was employed to guide a clinically oriented strategy, avoiding unnecessary passes and contrast overload when the angiographic result was grossly inadequate or there was no possibility to further increase CB diameter. This can explain the frequent occurrence of missing values in the various procedural steps.

\section{Conflict of interest statement}

All authors have no conflict of interest to declare.

\section{References}

1. Liistro F, Fineschi M, Grotti S, Angioli P, Carrera A, Ducci K, Gori T, Falsini G, Pierli C, Bolognese L. Long-term effectiveness and safety of sirolimus stent implantation for coronary in-stent restenosis results of the TRUE (Tuscany Registry of sirolimus for unselected in-stent restenosis) registry at 4 years. $\mathrm{J} \mathrm{Am} \mathrm{Coll} \mathrm{Cardiol}$ 2010 16;55:613-6.

2. Steinberg DH, Gaglia MA Jr, Pinto Slottow TL, Roy P, Bonello L, De Labriolle A, Lemesle G, Torguson R, Kineshige K, Xue Z, Suddath WO, Kent KM, Satler LF, Pichard AD, Lindsay J, Waksman R. Outcome differences with the use of drug-eluting stents for the treatment of in-stent restenosis of bare-metal stents versus drug-eluting stents. Am J Cardiol 2009;103:491-5.

3. Alfonso F, Pérez-Vizcayno MJ, Hernández R, Bethencourt A, Martí V, López-Mínguez JR, Angel J, Iñiguez A, Morís C, Cequier A, Sabaté M, Escaned J, Jiménez-Quevedo P, Bañuelos C, Suárez A, Macaya C; RIBS-II Investigators. Long-term clinical benefit of sirolimus-eluting stents in patients with in-stent restenosis results of the RIBS-II (Restenosis Intra-stent: Balloon angioplasty vs. elective sirolimus-eluting Stenting) study. J Am Coll Cardiol 2008;52: 1621-7.

4. Smith SC Jr, Feldman TE, Hirshfeld JW Jr, Jacobs AK, Kern MJ, King SB 3rd, Morrison DA, O'neill WW, Schaff HV, Whitlow PL, Williams DO, Antman EM, Smith SC Jr, Adams CD, Anderson JL, Faxon DP, Fuster V, Halperin JL, Hiratzka LF, Hunt SA, Jacobs AK, Nishimura R, Ornato JP, Page RL, Riegel B; American College of Cardiology/American Heart Association Task Force on Practice Guidelines; ACC/AHA/SCAI Writing Committee to Update the 2001 Guidelines for Percutaneous Coronary Intervention. ACC/ AHA/SCAI 2005 Guideline Update for Percutaneous Coronary Intervention-Summary Article: A Report of the American College of Cardiology/American Heart Association Task Force on Practice Guidelines (ACC/AHA/SCAI Writing Committee to Update the 2001 Guidelines for Percutaneous Coronary Intervention). J Am Coll Cardiol 2006;47:216-35.
5. Castagna MT, Mintz GS, Leiboff BO, Ahmed JM, Mehran R, Satler LF, Kent KM, Pichard AD, Weissman NJ. The contribution of "mechanical" problems to in-stent restenosis: An intravascular ultrasonographic analysis of 1090 consecutive in-stent restenosis lesions. Am Heart J 2001;142:970-4.

6. Iakovou I, Mintz GS, Dangas G, Abizaid A, Mehran R, Lansky AJ, Kobayashi Y, Hirose M, Ashby DT, Stone GW, Moses JW, Leon MB. Optimal final lumen area and predictors of target lesion revascularization after stent implantation in small coronary arteries. $\mathrm{Am} \mathrm{J}$ Cardiol 2003;92:1171-6.

7. Fujii K, Mintz GS, Kobayashi Y, Carlier SG, Takebayashi H, Yasuda T, Moussa I, Dangas G, Mehran R, Lansky AJ, Reyes A, Kreps E, Collins M, Colombo A, Stone GW, Teirstein PS, Leon MB, Moses JW. Contribution of stent underexpansion to recurrence after sirolimus-eluting stent implantation for in-stent restenosis. Circulation 2004;109:1085-8.

8. Gonzalo N, Serruys PW, Okamura T, van Beusekom HM, Garcia-Garcia HM, van Soest G, van der Giessen W, Regar E. Optical coherence tomography patterns of stent restenosis. Am Heart J 2009;158:284-93.

9. Suzuki Y, Ikeno F, Koizumi T, Tio F, Yeung AC, Yock PG, Fitzgerald PJ, Fearon WF. In vivo comparison between optical coherence tomography and intravascular ultrasound for detecting small degrees of in-stent neointima after stent implantation. JACC Cardiovasc Interv 2008;1:168-73.

10. Di Mario C, Barlis P. Optical coherence tomography: a new tool to detect tissue coverage in drug-eluting stents. JACC Cardiovasc Interv 2008;1:174-5.

11. Tyczynski P, Ferrante G, Kukreja N, Moreno-Ambroj C, Barlis P, Ramasami N, De Silva R, Beatt K, Di Mario C. Optical coherence tomography assessment of a new dedicated bifurcation stent. EuroIntervention 2009;5:544-551.

12. Prati F, Regar E, Mintz GS, Arbustini E, Di Mario C, Jang IK, Akasaka T, Costa M, Guagliumi G, Grube E, Ozaki Y, Pinto F, Serruys PW; Expert's OCT Review Document. Expert review document on methodology, terminology, and clinical applications of optical coherence tomography: physical principles, methodology of image acquisition, and clinical application for assessment of coronary arteries and atherosclerosis. Eur Heart J 2010;31:401-15.

13. Tanigawa J, Barlis P, Di Mario C. Intravascular optical coherence tomography: optimisation of image acquisition and quantitative assessment of stent strut apposition. EuroIntervention 2007;3: 128-36

14. Mehran R, Dangas G, Abizaid AS, Mintz GS, Lansky AJ, Satler LF, Pichard AD, Kent KM, Stone GW, Leon MB. Angiographic patterns of in-stent restenosis: classification and implications for longterm outcome. Circulation 1999;100:1872-8.

15. Barlis P, Gonzalo N, Di Mario C, Prati F, Buellesfeld L, Rieber J, Dalby MC, Ferrante G, Cera M, Grube E, Serruys PW, Regar E. A multicentre evaluation of the safety of intracoronary optical coherence tomography. EuroIntervention 2009;5:90-5.

16. $\mathrm{Ku} \mathrm{DN}$. Blood flow in arteries. Annual Review of Fluid Mechanics 1997;29:399. 
17. Fung YC, Liu SQ. Elementary mechanics of the endothelium of blood vessels. J Biomech Eng 1993;115:1-12.

18. Vito RP, Dixon SA. Blood vessel constitutive models-1995-2002. Annu Rev Biomed Eng 2003;5:413-39.

19. Oh S, Kleinberger M, McElhaney JH. Finite-element analysis of balloon angioplasty. Med Biol Eng Comput 1994;32:S108-14.

20. Lee MS, Singh V, Nero TJ, Wilentz JR. Cutting balloon angioplasty. J Invasive Cardiol 2002;14:552-6.

21. Adamian M, Colombo A, Briguori C, Nishida T, Marsico F, Di Mario C, Albiero R, Moussa I, Moses JW. Cutting balloon angioplasty for the treatment of in-stent restenosis: a matched comparison with rotational atherectomy, additional stent implantation and balloon angioplasty. J Am Coll Cardiol 2001;38:672-9.

22. Albiero R, Silber S, Di Mario C, Cernigliaro C, Battaglia S, Reimers B, Frasheri A, Klauss V, Auge JM, Rubartelli P, Morice MC, Cremonesi A, Schofer J, Bortone A, Colombo A; RESCUT Investigators. Cutting balloon versus conventional balloon angioplasty for the treatment of in-stent restenosis: results of the restenosis cutting balloon evaluation trial (RESCUT). J Am Coll Cardiol 2004;43:943-9.

23. Mehran R, Mintz GS, Popma JJ, Pichard AD, Satler LF, Kent KM, Griffin J, Leon MB. Mechanisms and results of balloon angioplasty for the treatment of in-stent restenosis. Am J Cardiol 1996;78: 618-22.

24. Shiran A, Mintz GS, Waksman R, Mehran R, Abizaid A, Kent KM, Pichard AD, Satler LF, Popma JJ, Leon MB. Early lumen loss after treatment of in-stent restenosis: an intravascular ultrasound study. Circulation 1998;98:200-3.

25. Mehran R, Dangas G, Abizaid AS, Mintz GS, Lansky AJ, Satler LF, Pichard AD, Kent KM, Stone GW, Leon MB. Angiographic patterns of in-stent restenosis: classification and implications for longterm outcome. Circulation 1999;100:1872-8.

26. Alfonso F, Cequier A, Angel J, Martí V, Zueco J, Bethencourt A, Mantilla R, López-Minguez JR, Gómez-Recio M, Morís C, PerezVizcayno MJ, Fernández C, Macaya C, Seabra-Gomes R; Restenosis Intra-stent Balloon angioplasty versus elective Stenting (RIBS) Investigators. Am Heart J 2006;151:681.e1-681.e9.

27. Sonoda S, Morino Y, Ako J, Terashima M, Hassan AH, Bonneau HN, Leon MB, Moses JW, Yock PG, Honda Y, Kuntz RE, Fitzgerald PJ; SIRIUS Investigators. Impact of final stent dimension on longterm results following sirolimus-eluting stent implantation: serial intravascular ultrasound analysis from the Sirius trial. J Am Coll Cardiol 2004;43:1959-63. 